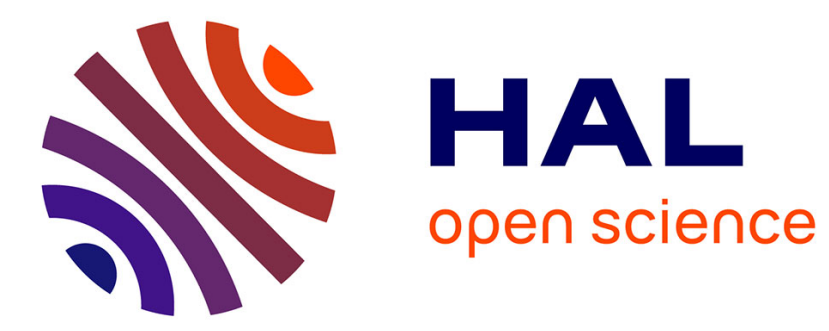

\title{
Seasonal insectivory of the Antillean fruit-eating bat (Brachyphylla cavernarum)
}

Arnaud Lenoble, Baptiste Angin, Jean-Bernard Huchet, Aurélien Royer

\section{To cite this version:}

Arnaud Lenoble, Baptiste Angin, Jean-Bernard Huchet, Aurélien Royer. Seasonal insectivory of the Antillean fruit-eating bat (Brachyphylla cavernarum). Caribbean Journal of Science, 2014, 48 (2-3), pp.47-51. 10.18475/cjos.v48i3.a01 . halshs-02501011

\section{HAL Id: halshs-02501011 https://shs.hal.science/halshs-02501011}

Submitted on 10 Jan 2022

HAL is a multi-disciplinary open access archive for the deposit and dissemination of scientific research documents, whether they are published or not. The documents may come from teaching and research institutions in France or abroad, or from public or private research centers.
L'archive ouverte pluridisciplinaire $\mathbf{H A L}$, est destinée au dépôt et à la diffusion de documents scientifiques de niveau recherche, publiés ou non, émanant des établissements d'enseignement et de recherche français ou étrangers, des laboratoires publics ou privés. 


\title{
Seasonal insectivory of the Antillean fruit-eating bat (Brachyphylla cavernarum)
}

\author{
Arnaud LENOBLE ${ }^{1 *}$, Baptiste ANGIN², Jean-Bernard $\mathrm{HUCHET}^{3}$, Aurélien ROYER ${ }^{1}$
}

1 - PACEA - UMR CNRS 5199, Université de Bordeaux, Allée G. St. Hilaire, Pessac Cedex, France

2 - Ardops environnement - 97115 Ste Rose - Guadeloupe F.W.I.

3 - MNHN - Laboratoire d'Entomologie, Institut de Systématique, Evolution, Biodiversité (ISYEB) UMR CNRS 7205 - 75005 PARIS, France

* Corresponding author: arnaud.lenoble@u-bordeaux.fr

ABSTRACT - This paper reports seasonal variations in the insect component of the Antillean fruiteating bat (Brachyphylla cavernarum) diet based on the study of guano from a colony on Guadeloupe. Fecal pellet content reveals that insects, mainly phytophagous scarab beetles (Coleoptera: Scarabaeoidea), can form an important part of Antillean fruit-eating bat feeding patterns, primarily at the beginning of the dry season.

Key words: Brachyphylla cavernarum, diet, Guadeloupe, guano, Insect consumption by fruit-eating bat, seasonality. 


\section{Introduction}

The Antillean fruit-eating bat (Brachyphylla cavernarum Gray 1834, family Phyllostomidae) is found throughout most of the Antillean archipelago, ranging from Barbados to Puerto Rico (Swanepoel and Genoways 1978). This species occupies a variety of habitats, including dry and moist topical forests as well as swamp forests and mangroves (Gannon et al. 2005, Ibéné et al. 2007). Baker and Genoways (1978) posited that geographical success of this species to be due to its varied diet. Feeding mainly on fruits, and to a lesser extent, pollen (Nellis 1971, Nellis and Ehle 1977, Gannon et al. 2005), the Antillean fruit-eating bat also consumes insects (Bond and Seaman 1958) in higher proportions compared to other frugivorous bats in the Caribbean (Taboada and Pine 1969). For example, Soto-Centeno et al (2001) noted insect remains in $66 \%$ of the fecal pellets they examined. Thus, despite its name, the Antillean fruit-eating bat is an omnivore (Pedersen et al. 2003). However, factors affecting the diversification of the B. cavernarum diet are still poorly understood. Here we report new data concerning diet variation of the Antillean fruit-eating bat from a colony in Guadeloupe.

\section{Materials and methods}

The study was carried out on the northeastern side of the volcanic island of Basse-Terre, in the now abandoned Grosse Montagne sugar factory $\left(16^{\circ} 13^{\prime} 54.5^{\prime \prime} \mathrm{N}\right.$ and $61^{\circ} 39^{\prime} 19^{\prime \prime} \mathrm{O}$ WGS 84$)$. This old factory is home to a large colony of $B$. cavernarum (Ibéné et al. 2007). Apart from less than a dozen mollossidae, $B$. cavernarum is the only species roosting in the factory, with a population estimated to number between five and ten thousand individuals. This important number of bats, present throughout the year, and including offspring strongly suggest a colony associating both males and females. Bats roost in the building north of the factory, which is also the part of the site where they least likely to be disturbed by light.

The study area receives an average annual rainfall of $1850 \mathrm{~mm}$ and the mean annual temperature is $27^{\circ} \mathrm{C}$, conditions which create moderate seasonality. The surrounding areas are dominated by banana and sugar fields or residential developments with widespread exotic plants, while moist tropical forests are found in the riparian zones of valley bottoms. Guano was collected at the beginning of each month from June 2013 to May 2014. Thick plastic sheets were placed on the ground at different locations around the base of the main bat clusters, for a total collection area ranging between 0.9 and $1.2 \mathrm{~m} 2$. The plastic films were replaced monthly. The accumulated guano was collected, then dried to avoiding any sample modification (e.g. rotting), and inventoried. Guano samples consist of amorphous black and Seaman 1958, Picard and Catzeflis 2013) and insect fragments. The samples were sent to the PACEA laboratory at the University of Bordeaux, where plant and insect remains were categorized according to their nature and weighted. Insect remains were identified by one of us (JBH) based on comparisons with West Indies reference specimens in the entomological collections of the Muséum National d'Histoire Naturelle in Paris.

\section{Results}

Bats roost in the factory throughout the year, and no perceptible changes in the size of the colony were noted during the sampling year, except for November and December, where an estimated $30 \%$ decrease in the number of individuals was observed. Isolated insect fragments were recovered, including heads, antennae, elytrons and legs. The insect remains retained their original morphology and colors, indicating low degradation of these chitinous fragments by gastric acids in the bat's stomachs.

Beetle remains are by far the most numerous, comprised almost exclusively of members of the superfamily Scarabaeoidea, represented by a particularly large proportion of phytophagous species, 
namely Melolonthidae (Phyllophaga sp.) and Dynastidae (genus Cyclocephala Latreille and Ligyrus Burmeister). Non-scarab beetles were represented by more or less complete larvae or imago of the black fungus beetle Alphitobius laevigatus (Fabricius, 1781) (Tenebrionidae). This detritivorous species is commonly found in cave guano (Peck 2006, 2009). In the present case, specimens were mostly found complete, indicating their occurrence to be related to the guanophile behavior of this species. Hair was also abundant in the samples collected in June, July, and August, in others words, just after the parturition period (Swanoepel and Genoways 1983). This consequently suggests hair loss to be related to lactating as noted by Genoways et al. (2001), or postjuvenile molt giving way to adult pelage in the young of the year.

Insects consumed by B. cavernarum account on annual average of $26.7 \%$ of the guano by dry weight. The proportion of insect remains in the guano probably overestimates the contribution of insects in bat diet due to their chitinous exoskeleton; $10 \mathrm{~g}$ of beetles consumed by a bat are likely to produce more guano than $10 \mathrm{~g}$ of fruit. As a consequence, the ratio between dry mass of vegetal matter and insects probably does not accurately reflect the relative contribution of each source to the bat diet. However, our data reveals significant variation in the representation of insect remains, ranging from 3 to $54 \%$ of the guano's dry weight depending on the month. Shifts in the insect proportion of the diet follow a cyclical pattern during the year (Figure 1). Highly significant differences can be seen between the first four months of the dry season (December to March) and the rest of the year (MannWhitney U-test $U=0$ and $p=0.0085$ ), with the proportion of insect remains being lowest between June and September (i.e. the wet season) and highest in December and January at the beginning of the dry season

\section{Discussion}

Mango (Mangifera indica), guava (Psidium goyava), and figs (Ficus sp.) represent a significant portion of the diet in the Antillean fruit-eating (Nellis and Ehle 1977, Picard and Catzeflis 2013) from May to October. Pollen and nectar of plants that flower during the dry season, such as silk-cotton (Ceiba pentadra) or the Portia tree (Thespesia populnea), represent an alternate food resource during periods of low-fruit availability. Observations carried out on the nearby islands of Montserrat and Nevis indicate that during periods of severe drought or following natural hazards, the Antillean fruit bat is able to adapt its feeding patterns to include alternate plant species, such as flowers, false tamarind leaves and pods (Leucaena leucocephala), cocoa pods (Theobroma cacao), and sour orange fruits (Citrus auratinum) (Pedersen et al. 2003). Data gathered from the Grosse Montagne factory show that during the dry period, Antillean fruit-eating bats supplement their diet with large quantities of insects, confirming the dietary flexibility of the Antillean fruit bat.

A shift from a predominantly phytophagous to an insectivorous diet has been documented for other phyllostomids in South America (e.g. Barros et al 2013, Zortea 2013). In regions with strong seasonality, insect consumption peaks during the dry season (Pedro and Taddei 1997, Zortea 2003), which has been correlated with reduced fruit availability and an expansion of the feeding niche to include insects (Pedro and Taddei 1997). Insects consumed by B. cavernarum roosting in Grosse Montagne factory are almost exclusively beetles and include very high proportions of Scarabaeoidea, namely Phyllophaga Harris and Cyclocephala Latreille, which are among the most common genera in the Caribbean. While Phyllophaga are present year-round, adults are the most abundant during the months of May and June (Chalumeau 1983), hence the name "May Beetles". As demonstrated by Tanaka and Tanaka (1982) for Grenada, insect biomass, particularly beetles, is maximal during rainy season, but is still important during the first two months of the dry season, with an abundance exceeding half the peak values of the year. In the late dry season, this biomass subsequently decreases by a factor of three. Thus, the high proportion of these beetles in the samples collected in December and January shows that insect consumption by $B$. cavernarum is not directly controlled by insect abundance in the environment. Instead, it mirrors a balance between insect abundance and fruit 
availability. Data from the fecal samples collect from the Grosse Montagne factory suggest (a) that the Antillean fruit bat is mainly phytophagous, as indicated both by the greater proportion of vegetal component of the guano on the whole year and the very low occurrence of insect remains in the guano of the rainy season during which beetles are the most abundant, and (b) that insects play a central role in the diet during the two first months of the dry season when the bat expands its food niche and available insect biomass remains high. This flexibility, which enables this bat to survive major environmental changes, as suggested by Genoways and Baker $(1978)$ or Pedersen et al. $(1996,2007)$, may be one of the reasons underlying the species' geographical success.

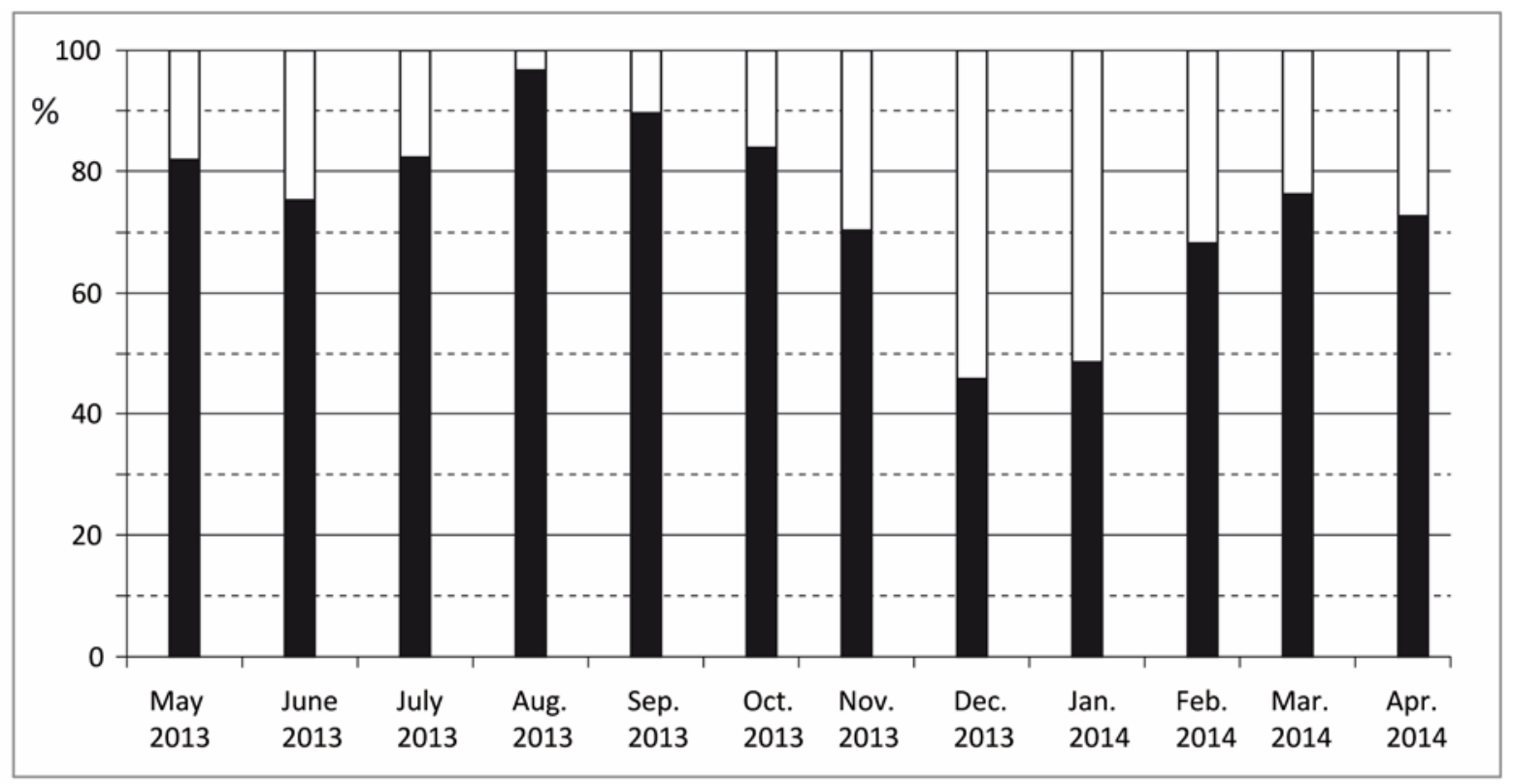

Fig. 1: Monthly proportions of plant and insect remains (dry mass) in the guano of Brachyphylla cavernarum collected at the Grosse Montagne factory. Black bar: proportion of vegetal mass; white bar: proportion of insects remains.

Observations made during the site visits do not indicate that changes in colony size we observed in November and December were due to human disturbance. Nor is it possible to link which occurs in the spring (Swanepoel and Genoways 1983, Pedersen et al. 2003, Gannon et al. 2005, Genoways et al. 2007). Thus, the decrease in the number of individuals forming the colony could be a consequence of poor food availability in the roost's immediate environment. However, this assumption fails to explain why the colony returns to its usual size during the mid-dry season (January), when food availability still remains low. Alternate roost occupations are also thought to be driven by factors such as the departure of the year pups or the avoidance of sites heavily infested by parasites (Pedersen et al. 2012). Resolving this issue, however, requires more detailed studies which takes into account all components of the bat diet as well as a thorough analysis of others aspects of bat biology.

It is worth mentioning that the roost we studied is located on the north-western slopes of the volcanic island of Basse-Terre, in an area $5 \mathrm{~km}$ from the rainforest covering the volcanic uplands, where the seasonality of flowering is mitigated by regular, year-round rainfall (Lasserre 1961). The bats roosting in the old factory therefore have access to plant resources within the rainforest throughout the year. The situation is different for bats occurring on islands with dry forests and more obvious seasonality, such as the nearby island of Barbuda (Pedersen et al. 2007). Therefore, the proportion of insects in the diet of $B$. cavernarum could be even more important on drier islands compared to what was observed for the Grosse Montagne colony. As a consequence, results obtained from this study 
demonstrate the necessity of taking into account the season when bats are observed in order have the most accurate picture of the diet of $B$. cavernarum.

\section{Acknowledgments}

This study was conducted as a part of the BIVAAG Program established by the CNRS, with support from a European PO-FEDER grant 2007-2013 $n^{\circ} 2 / 2.4 /-33456$, the Guadeloupe Regional Council, the DEAL of Guadeloupe, and the DAC of Guadeloupe. We would like to thank A. Vignoles for her help during guano analysis, as well as M. Barataud, F. Catzeflis, D. Imbert, and R. Picard for their constructive comments during data analysis. We are also grateful to $S$. C. Pedersen and an anonymous reviewer who greatly helped to improve this paper.

\section{Literature cited}

Baker, R. J., and H. H. Genoways. 1978. Zoogeography of Antillean bats. Zoogeography of the Caribbean 13:1-128.

Barros, M., A. M. Rui and M. E. Fabian. 2013. Seasonal variation in the diet of the bat Anoura caudifer (Phyllostomidae: Glossophaginae) at the southern limit of its geographic range. Acta Chiropterologica 15(1):77-84.

Bond, R. M. and G. A. Seaman. 1958. Notes on a colony of Brachyphylla cavernarum. Journal of Mammalogy 39(1):150-151.

Chalumeau, F. 1983. Coléoptères Scarabaeides des Petites Antilles. Encyclopédie entomologiqueXLIV. Paris: Lechevalier.

Gannon M. R., A. Kurta, A. Rodiriguez-Duran and M. R. Willig. 2005. Bats of Puerto Rico: An island focus and Caribbean perspective. Lubbock: Texas Tech Univ. Press.

Genoways H. H., C. J. Phillips, R. M. Timm and D. A. Schlitter. 2001. Bats of the West Indian island of Dominica: natural history, areography, and trophic structure. Mammalogy Papers: University of Nebraska State Museum 105, 48 p.

Genoways, H. H., S. C. Pedersen, L. K. Gordon and C. J. Phillips. 2007. Bats of Anguilla, Northern Lesser Antilles. Mammalogy Papers: University of Nebraska State Museum, 12p.

Heithaus E. R., T. H. Fleming and P. A. Opler. 1975. Foraging Patterns and Resource Utilization in Seven Species of Bats in a Seasonal Tropical Forest. Ecology 56(4):841-854.

Ibéné B., F. Leblanc, C. Houllemare, C. Tarlier and C. Pentier. 2007. Contribution à l'étude des Chiroptères de la Guadeloupe. Basse-Terre: Diren Guadeloupe, 132 p.

Lasserre G. 1961. La Guadeloupe, étude géographique. Bordeaux: Union française d'impression.

Nellis D. W., and C. P. Ehle. 1977. Observations on the Behavior of Brachyphylla cavernarum (Chiroptera) in Virgin Islands. Mammalia 41(4):403-410.

Pedersen, S. C., H. H. Genoways and P. W. Freeman. 1996. Notes on Bats from Montserrat (Lesser Antilles) with comments concerning the effects of hurricane Hugo. Carribean Journal of Science 32(2):206-213.

Pedersen S. C., H. H. Genoways, M. N. Morton, J. W. Johnson and S. E. Courts. 2003. Bats of Nevis, Northern Lesser Antilles. Acta Chiropterologica 5(2):251-67.

Pedersen S. C., G. G. Kwiecinski, P. A. Larsen, M. N. Morton, R. A. Adams, H. H. Genoways, and V. J. Swier. 2010. Bats of Montserrat: Population Fluctuation and Response to Hurricanes and Volcanoes, 1978-2005. In Island bats: evolution, ecology, and conservation, eds. T. H. Fleming and P. A. Racey, 302-340. Chicago: University of Chicago Press.

Pedersen S. C., P. A. Larsen, H. H. Genoways, M. N. Morton, K. C. Lindsay and J. Cindric. 2007. Bats of Barbuda, Northern Lesser Antilles. Museum of Texas Tech University Occasional Papers 271:1-20. 
Pedersen S. C., T. E. Popowics, G. G. Kwiecinski and D. E. Knudsen. 2012. Sublethal pathology in bats associated with stress and volcanic activity on Montserrat, West Indies. Journal of Mammalogy 93(5):1380-1392.

Pedro W. A., and V. A. Taddei. 2002. Temporal distribution of five bat species (Chiroptera, Phyllostomidae) from Panga Reserve, south-eastern Brazil. Revista Brasileira de Zoologia 19(3):951-954.

Peck S. B., A. E. Ruiz-Baliú and G. F. Garcés González. 1998. The Cave-inhabiting Beetles of Cuba (Insecta: Coleoptera): Diversity, Distribution and Ecology. Journal of Cave and Karst Studies 60(3):156-166.

Peck S. B. 2006. The beetle fauna of Dominica, Lesser Antilles (Insecta: Coleoptera): Diversity and distribution. Insecta Mundi 20(3-4):165-208.

Peck S. B. 2009. The beetles of Barbados, West Indies (Insecta: Coleoptera): diversity, distribution and faunal structure. Insecta Mundi 0073:1-51.

Picard R. and F. Catzeflis. 2013. Première étude des chauves-souris dans les goyaveraies de Martinique. In Biodiversité insulaire: la flore, la faune et l'homme dans les Petites Antilles, 174183. Fort-de-France, Martinique: Direction de l'Environnement, de l'Aménagement et du Logement de Martinique et Université des Antilles et de la Guyane.

Soto-Centeno J. A., A. Rodriguez-Duran and E. Cortes Rosa. 2001. Erophylla sezekorni and Brachyphylla cavernarum Diet of Two Phyllostomid Bats in Puerto Rico. Bat Research News 42(4):180-181.

Swanepoel P. and H. H. Genoways. 1978. Revision of the Antillean bats of the genus Brachyphylla (Mammalia: Pyllostomatidae). Bulletin of the Carnegie Museum of Natural History 12:1-53.

Swanepoel P. and H. H. Genoways. 1983. Brachyphylla cavernarum. Mammalian Species 205:1-6.

Taboada G. S. and R. H. Pine. 1969. Morphological and Behavioral Evidence for the Relationship between the Bat Genus Brachyphylla and the Phyllonycterinae. Biotropica 1(1):10-19.

Tanaka L. K., and S. K. Tanaka. 1982. Rainfall and seasonal changes in arthropod abundance on a tropical oceanic island. Biotropica 14(2):114-123.

Zortéa M. 2003. Reproductive patterns and feeding habits of three nectarivorous bats (Phyllostomidae: Glossophaginae) from the Brazilian Cerrado. Brazilian Journal of Biology 63(1):159-168. 